\title{
RETROBULBAR FIBROSARCOMA IN A SHEEP
}

\author{
OZMEN Ozlem*, SIRIN SENGOZ Ozlem², ÇINAR Harun², DOLU Hüseyin ${ }^{1}$
}

${ }^{1}$ Mehmet Akif Ersoy University, Faculty of Veterinary Medicine, Department of Pathology, Istiklal Yerleskesi, 15030, Burdur, Turkey; ${ }^{2}$ Mehmet Akif Ersoy University, Faculty of Veterinary Medicine, Department of Surgery, Istiklal Yerleskesi, 15030, Burdur, Turkey.

(Received 23 November 2015; Accepted 24 February 2016)

This report describes a case of a retrobulbar fibrosarcoma in a 4-year-old female sheep. A big tumor was protruding from the orbit but not invading the surrounding tissue and was easily removed surgically. The grayish colored mass was $19 \times 13 \times 8 \mathrm{~cm}$ in size and hard. The surface of the tumor was irregular and ulcerated. Marked hemorrhage and necrotic areas were present across the whitish cut surface. Histopathologically, the mass was composed of spindle shaped, anaplastic pleomorphic cells. Masson's trichrome staining revealed a collagenous matrix in the tissue. Immunohistochemically, the mass was positive for vimentin and proliferating cell nuclear antigen but negative for smooth muscle actin, desmin, glial fibrilar acidic protein and S100 protein antibodies. According to histopathological and immunohistochemical findings the tumor was diagnosed as fibrosarcoma. To the authors' knowledge, this is the first report of ocular fibrosarcoma in a sheep.

Key words: Retrobulbar fibrosarcoma, histopathology, immunohistochemistry, sheep

\section{INTRODUCTION}

Fibrosarcoma is a malignant tumor of the connective tissue which originates from fibroblasts. It has variable presentations depending on species, age, site, and etiopathogenesis. Fibrosarcomas are usually localized subcutaneously but they may originate from visceral organs. Although this tumor occurs in all animals, it is most commonly observed in old cats and dogs [1,2].

Ocular tumors are generally seen in dogs, cats and cattle. Squamous cell carcinoma was the predominant type of eyelid neoplasm in cattle, cats and sheep while melanocytic tumors are commonly seen in dogs [1-7]. Ocular fibrosarcomas may develop in the orbit of cats with pthysis bulbi, ocular trauma or ocular foreign bodies [8]. Very rare reports are available about ocular fibrosarcoma in cattle [4,9]. Tumors in sheep are diagnosed very rarely except squamous cell carcinoma and there is no ocular fibrosarcoma reported in sheep.

\footnotetext{
*Corresponding author: e-mail: ozlemozmen@mehmetakif.edu.tr
} 
The aim of this study was to report clinical and pathological findings of an ocular fibrosarcoma in a sheep.

\section{Case Presentation}

A 4 year-old-female sheep with late pregnancy presented with loss of appetite and bleeding, with an infected mass covering the right eye. Since the tumor mass was not infiltrative into the surrounding tissue, surgical dissection and removal of the mass was easily carried out.

Extirpation of the orbital cavity was performed after a retrobulbar injection of $15 \mathrm{ml}$ $2 \%$ lidocaine and linear infiltration analgesia at the upper and lower eyelids. Sharp and blunt dissection continued between the globe and bones of the orbit until complete excision of the globe. Eyelids were sutured with interrupted prolene stitches.

Surgical incision healed without any complication and sutures were removed on the 10th day after surgery. No complications or recurrence were observed up to 3 months postoperative surgical extirpation.

After total extirpation of the eye, the mass was submitted to the department of pathology for histopathological analysis. The mass was 19x13x8 cm, hard, and grayish in color with hemorrhagic and necrotic areas evident on both surfaces of the incision (Fig. 1). For histopathological examination tissue samples were fixed in 10\% buffered formalin and processed routinely for light microscopy. Five micron thick sections were taken from paraffin embedded tissues and stained with Hematoxylin- Eosin (HE) and Masson's trichrome method for light microscopy (Fig. 2A-B).

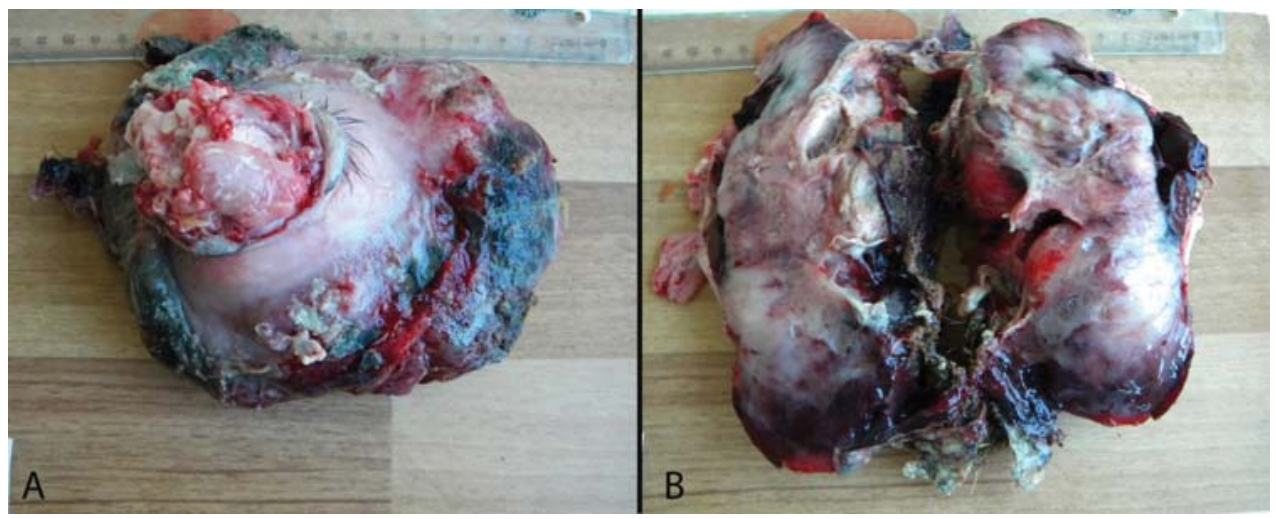

Figure 1. Gross appearance (A) and cut surface of the tumor (B)

On the HE stained slides, the tumor was composed of anaplastic, pleomorphic, spindleshaped cells separated by abundant eosinophilic collagen fibers. The neoplastic cells had an oval or irregular shape, numerous bizarre, sometimes giant cells with multiple nuclei. The nucleus had a marginal chromatin with prominent one or more nucleoli. The cytoplasm of the cells was eosinophilic and marked anisocytosis was observed. Inflammatory cells i.e. mainly neutrophils were present in the ulcerated areas of the 
tumor. Mitotic activity was increased in the tumor. There was no invasion of the tumor into observed eye structures. Masson's trichrome method revealed a marked collagenous matrix in the mass (Fig. 2C).

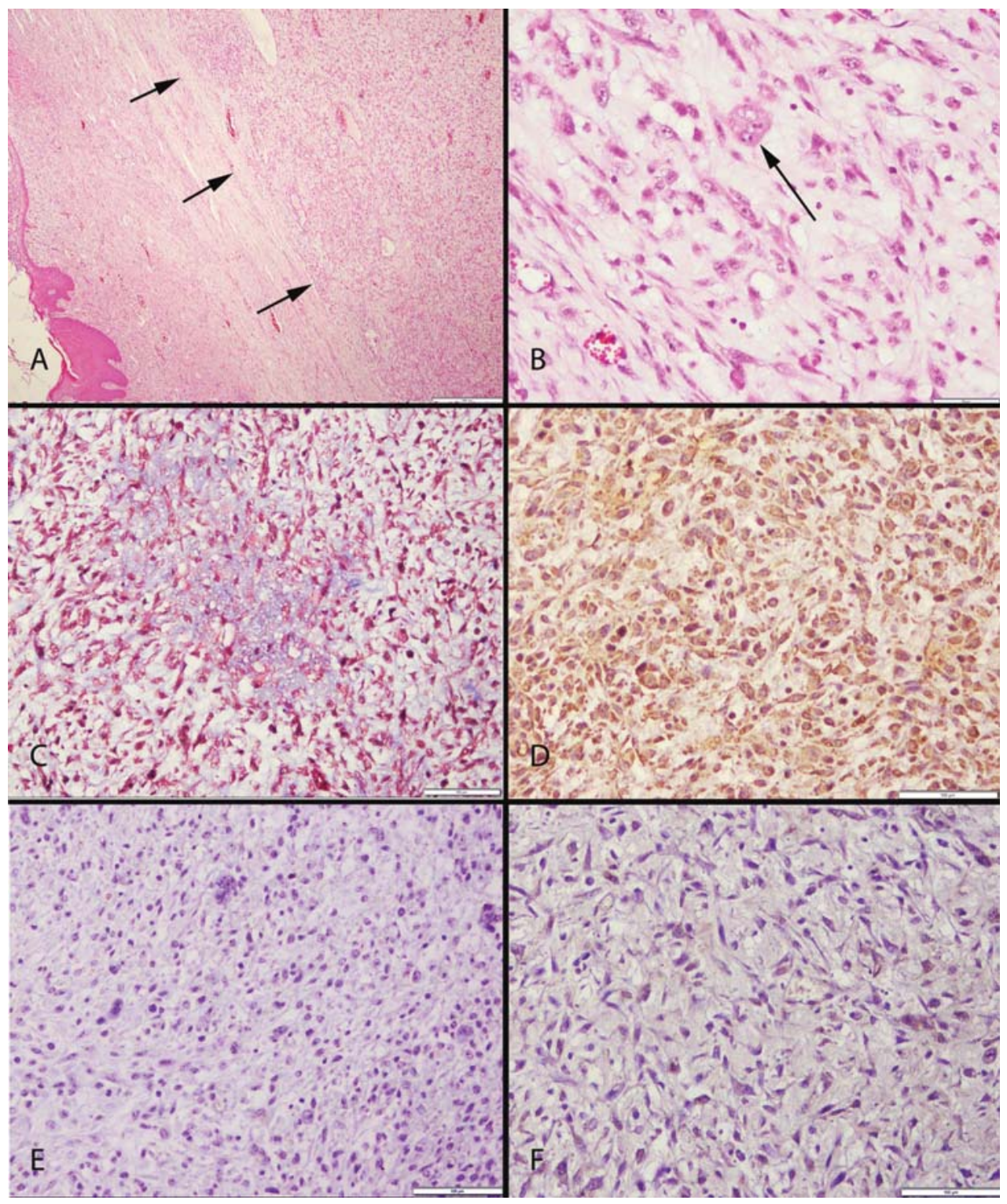

Figure 2. (A) Histopathological appearance of the tumor, under the dermis (arrows), HE, Bar= $500 \mu \mathrm{m}$; (B) Higher magnification of the tumor, pleomorphic and anisocytic cell, and giant cells

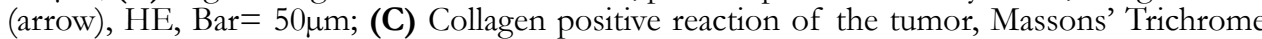
Method, Bar=100 $\mu \mathrm{m}$; (D) Vimentin positive immunoreaction of the tumor, Streptavidin Biotin Peroxidase Method, Bar $=100 \mu \mathrm{m}$; (E) Desmin negative immunoreaction of the tumor, Streptavidin Biotin Peroxidase Method, Bar $=100 \mu \mathrm{m}$; (F) GFAP negative immunoreaction of the tumor, Streptavidin Biotin Peroxidase Method, Bar $=100 \mu \mathrm{m}$. 
Selected tissue sections were stained immunohistochemically in order to demonstrate the origin of the cells and malignity. Commercial kits provided from, Abbiotech, San Diego, CA were used at a 1:100 dilution for immunohistochemical examination of proliferating cell nuclear antigen (Rabbit polyclonal PCNA antibody, 250812); desmin (mouse monoclonal desmin antibody, 251743); Vimentin (mouse monoclonal vimentin antibody, 251809); smooth muscle actin (mouse monoclonal SMA, 251813); S100 (mouse monoclonal S-100 antibody, 251795), glial fibrillary acidic protein (rabbit polyclonal GFAP antibody, 250661) using a routine streptavidine-biotin peroxidase technique.

Immunohistochemically, the mass was positive for vimentin and PCNA, but negative for SMA, desmin, GFAP and S100 protein antibodies. Fibrosarcoma was diagnosed according to histopathological and immunohistochemical findings of the mass (Fig 2D-F).

Ocular pathology is a new area of veterinary medicine that studies pathological processes that affect the eye bulb and its adnexal structures [5]. One of the most common pathologies of the eyes tumors and they are generally seen in cats and dogs [10]. Ovine ocular neoplasms are in general quite uncommon $[1,5]$. The most common ocular tumor reported in sheep is squamous cell carcinoma [1,2]. Fibrosarcomas originate from connective tissue and are commonly localized under the skin, however they may be localized in any other organ [2]. Ocular localization of fibrosarcomas is very rare and they are reported only in cats and cattle $[4,8]$. There is no report available about ocular localization of fibrosarcoma in sheep and this is the first ocular fibrosarcoma report in this species.

Primary tumors of the eye may arise from the eyelids and adnexa, from the optic nerve, or within the globe. Dogs and cats are most frequently affected, primary intraocular neoplasms are inexplicably rare in other domestic species [9]. In this study, the ocular tumor was diagnosed as fibrosarcoma based on histopathological examination. There was no invasion in the eye grossly or microscopically. During pathological examination the origin of the tumor was determined as retrobulbar connective tissue.

Differential diagnosis of fibrosarcomas needs immunohistochemistry or collagen staining $[2,10,11]$. In this study fibrosarcoma diagnosis was supported by Masson's trichrome method and immunohistochemistry.

As sheep and goats are slaughtered for meat production at an early age, the exact occurrence of tumors cannot be determined. Although tumors in animals appear at any period of life, they generally occur during older ages, but the peak ages of tumor incidence are different for each species. The peak age of incidence is unknown in sheep and goats [1]. In the present case the tumor was diagnosed in a 4 years old sheep and the idea of a correlation between higher age and tumor development is thus supported.

Local extirpation and total bulbar extirpation for the treatment of ocular neoplasms are applicable and inexpensive methods with low complication risks. In the present 
study, because of the size and localization of the tumor total extirpation was used as the treatment of choice and no recurrence was observed during the following 3 months.

As a conclusion, a case of retrobulbar fibrosarcoma is hereby reported with clinical, pathological and immunohistochemical findings in a 4-year old sheep.

\section{Authors' contributions}

00 carried out the histopathological and immunohistochemical examination, and drafted the manuscript. OSS carried out the surgical treatment. HÇ participated to the surgery. HD performed the laboratory procedures. All authors read and approved the final manuscript.

\section{Declaration of conflicting interests}

The author(s) declared no potential conflicts of interest with respect to the research, authorship, and/or publication of this article.

\section{REFERENCES}

1. Goldschmidt MH, Hendrick MJ: Tumors of the skin and soft tissues. In: Tumors in Domestic Animals, Ed Meuten DJ, Ames, IA, Iowa State Press; 2002, 84-85.

2. Erer H, Kiran MM: Fibrosarkom. In: Veteriner Onkoloji, Konya, Turkey; Bahcivanlar Basim Sanayi AS; 2009, 84-85.

3. Maggs DJ: Eyelids. In: Slatter's Fundamentals of Veterinary Ophthalmology, Eds Maggs D, P. Miller, R. Ofri, $4^{\text {th }}$ ed., St Louis,USA; Saunders Elsevier; 2008, 107-134.

4. Ceylan C, Ozyildiz Z, Yilmaz R, Biricik HS: Clinical and histopathological evaluation of bovine ocular and periocular neoplasms in 15 cases in Sanliurfa region. J Fac Vet Med Kafkas Univ 2012, 18 (3): 469-474.

5. Martins TB, Barros CSL: Fifty years in the blink of an eye: a retrospective study of ocular and periocular lesions in domestic animals. Pesquisa Vet Brasil 2014, 34(12): 1215-1222.

6. Fischer CA, Lindley DM, Carlton WC, Van Hecke H: Tumors of the Cornea and Sclera. In: Ocular Tumors in Animals and Humans, Eds Peiffer RL, KB Simons, Ames, IA, USA; Iowa State Press 2002, 149-202.

7. Finn M, Krohne S, Stiles J: Ocular melanocytic neoplasia. Compen Cont Educa Vet 2008, 30: 19-25.

8. Infante JF, Zaldivar N, Sanchez R: Ocular fibrosarcoma in a cow. Rev Salud Anim 1985, 7 (2): 239-240.

9. Wilcock BP: Ocular neoplasia. In: Jubb, Kennedy, and Palmer's Pathology of Domestic Animals, Ed. Maxie MG, $5^{\text {th }}$ ed., Philadelphia, USA; Elsevier Saunder; 2007, 531-535. 
10. Ober C, Gal AF, Miclaus V, Pestean C, Taulescu M, Bel L, Catoi C, Ona L. Description of an anaplastic rhabdomyosarcoma in a cockatiel (nymphicus hollandicus). Acta Vet Beog 2015, 65 (3): 436-442.

11. Feghiu A, Cringanu D, Dumitrescu F, Pascal M, Vasilescu F, Militaru M. Nasal transmissible venereal tumor in a jack russel terrier bitch. Acta Vet Beog 2015, 65 (1): 143-148

\section{RETROBULBARNI FIBROSARKOM KOD OVCE}

OZMEN Ozlem, SIRIN SENGOZ Ozlem, ÇINAR Harun, DOLU Hüseyin

Ovaj rad prikazuje slučaj retrobulbarnog fibrosarkoma kog ovce stare 4 godine.Veliki tumor je prominirao iz orbite, ali bez invazije okolnih tkiva te je lako otklonjen hirurškim putem. Sivo obojena čvrsta masa je bila dimenzija 19x13x8cm. Površina tumora je bila nepravilna, sa ulceracijama. Izražene hemoragije i nekrotična polja bila su prtisutna na beličastoj površini preseka. Histopatološki, masu su činile vretenaste i anaplastične pleomorfne ćelije. Masson-trihrom bojenje je otkrilo kolageni matriks u tkivu. Imunohistohemijski masa je bila pozitivna na vimentin I proliferišućih ćelija nuklearni antigen, ali negativne na actin glatkih mišića, dezmin, glialni fibrilarni kiseli protein i S100 protein antitela. U skladu sa histopatološkim i imunohistohemijskim nalazima tumor je dijagnostikovan kao fibrosarkom. Prema saznanjima kojima raspolažu autori ovo je prvi prijavljeni slučaj retrobulbarnog fibrosarkoma kod ovce. 